requirements laid down by the departments, including minor theses, qualifying examinations, and supplemental research projects.

$$
\begin{aligned}
& \text { Yours faithfully, } \\
& \text { JAY M. PASACHOFF }
\end{aligned}
$$

\author{
Hale Observatories, \\ Carnegie Institution of Washington, \\ California Institute of Technology, \\ Pasadena, California 91109
}

\section{Bird Navigation}

Sir,- - Two points appear to be misleadingly used to indicate that domesticateal Columba livia does not require sun-azimuth for route-finding when your correspondent on the homing sense in pigeons (Nature, 232, 86; 1971) stated: "Recent evidence that this ("map" mind of the homing bird) can operate effectively even after many days' imprisonment away from the home loft ..." I published elsewhere ${ }^{1}$ examples of very long memory in pigeons including the following: a Hollywood (USA) pigeon which raced up to 500 miles, 1931-4, sold to Huntington (California) which returned on escape after kept "prisoner" 8 years; one lost racing Rennes (France) to Manchester, 1926, which returned home 1931, after presumably being stolen and kept prisoner; an Australian pigeon lost racing 550 miles BenalloMelbourne, 1944, which returned in 1948, and another which returned 400 miles to France 2 years after sale to Newcastle, where it was kept prisoner a year. I have known pigeons lost up to a year return to their old nest-boxes, among many inside a breeding loft, and fight the new owner for occupation. As the breeding season approaches, more lost birds home than otherwise.

In all such cases which could be investigated, the birds were kept as "inside" prisoners without sky-views. Where transported birds are kept prisoner a week or more in outside, mesh-wire "aviaries", they "resettle" to the new territory. Young birds (6 months old) have thus been resettled in 1 week, exceptionally in 4 days; but older birds usually require 8 to 10 days. My operational birds in the British Army Pigeon Service in the $1939-45$ war were sent forward in baskets (to be flown back to their lofts) with the instruction "it is important that birds should be so placed that it is impossible for them to see their immediate external surroundings", and that unused birds should not be kept in delivery or stock baskets for more than 4 days (in trench-baskets, 3 days), but returned for replacements. This was to avoid birds "seeing" and "remembering" the new temporary release-point.

Visual recognition of their external surroundings (e.g. sky and landscape was used to resettle birds to "home" to new loft-sites in place of old ones, using outside aviaries or baskets on top of the loft for at least an hour daily. I allowed my loftmen a minimum of a fortnight to settle pigeons to a new loft-site, but preferred 5 weeks (longer still for distances over 30-50 miles). We once settled thirty-four birds to "home" to a new loft site in 10 days. I have no evidence of birds settled to fly to a new loft-site by "inside" imprisonment, without external views, excepting the "nomad" type of training where a pigeon homed to a marked mobile loft, or basket, by recognition of the mark used also when feeding it.

While ability to home is known to be inherited (an untrained 2-months-old pigeon still squeaking homed 40 miles to one of my lofts, where it was bred) the homing territory is acquired after birthpigeon eggs taken 100 miles to be hatched and reared "home" to the loft where they were reared, not where the eggs were laid. Pigeons returning to Scotland continued through the longer light of Scottish summer nights to arrive earlier than birds roosting in the darker English night before reaching English lofts. Pigeons liberated in fog distinct from merely ground-mist, are delayed, presumably by waiting for visibility to clear.

The more remarkable test of astral and sun navigation is not this long delayed homing of pigeons, but the annual return to the same breeding and wintering territories by trans-equatorial migrants, particularly the purely marine southern petrels and shearwaters, whose journeys cover seas with no landmarks. Yours faithfully, ERIC HARDY

Merseyside Naturalist's Association, 47 Woodsorrel Road, Liverpool 15

'Hardy, E., Pigeon Guide: A. Complete Handbook of Pigeon Keeping (Seeley, London, 1951).

\section{Black Hole to the North?}

SIR,--I read with extreme interest the editorial observation that, over the past ten years, "the population in the extreme North of Britain decreased, with Lancashire, Cumberland and Northumberland all returning figures lower than in $1961 \ldots " 1$ thus confirming the fears of those of us who dwell beyond the pale in the thirty-one counties of mainland Britain on the wrong side of Hadrian's Wall, that in fact we really do have no existence and that contracting population acting like some contracting stellar body has pulled the land mass with it leaving a "black hole" to the north of Carlisle.

Or perhaps the statement showed a trace of Anglo-Chauvinism in confusing the land of the English with the island of
Great Britain?-an inauspicious error in a journal dedicated to the objective accuracy of science.

$$
\begin{aligned}
& \text { Yours faithfully, } \\
& \text { WILliam F. DRYDEN }
\end{aligned}
$$

Department of Pharmacology,

Royal College,

George Street, Glasgow C1

${ }^{1}$ Nature, 232, 512 (1971).

\section{Unfair to Scientists}

SIR,-During the period when the pay of civil service scientists has been the subject of public debate most of us concerned with the matter have felt the reports in Nature to be well balanced and to fairly state the case of both sides. Your conclusions have represented a fair assessment of the merits of the case. But, then, we could expect you as a serious commentator on scientific affairs to recognize what enormous damage would be done to the scientific community at large by the Civil Service Department's ludicrous pay offer to its scientific staffs. I should like, however, to emphasize the following points.

Regrettably, the arbitration tribunal has done nothing to resolve the basic problem. Anyone trying to reconcile the irreconcilable is likely to produce a nonsensical result. That was bound to be the outcome of trying to bring together "fair comparisons" and internal relativities. The Civil Service Department at least recognized the problem. They acknowledged that there were special circumstances affecting the pay of scientists but argued that they were irrelevant and, in any case, could not be measured. Thus, for them, there was no conflict. We were not prepared, and are not now, to have scientists treated as poor relations of their civil service colleagues in the technological field, nor yet of those in administration.

We will not take part in another pay research exercise and we are determined to get a joint review to establish a proper basis for future pay reviews for scientific staffs. We will press for early action on all of the structure aspects of Fulton, including the point which you rightly make about the need for scientists (and other specialists) to move across to more general administration. In part, of course, the point can be met by proper systems of accountable management but there will remain a need to move away from science for those who are going to get right to the top.

Neither this alone, nor in combination with your other point of allowing greater freedom to leave the civil service (a subject on which we are currently in discussion with CSD) will resolve the main problem. This remains the need to provide the great majority of scientific 
staffs-who will not become Chief Scientists or Permanent Secretarieswith a pay and career structure which matches that of those of their colleagues whose job weight, background and qualifications is unquestionably in no way superior to their own. That is not the case now; we are quite determined that it shall become so.

All this is far removed from your suggestion that we may become "entirely lost in detailed quibbles", or that we are taking an insufficiently radical view of what is needed. I should have thought that our aims are precisely those which would result in scientists assuming their rightful position in the Service. As you have recognized, it will be a sorry day for science and scientists generally if we fail. We do not intend to fail; there is too much at stake.

\section{Yours faithfully, \\ Cyril CoOper}

Deputy General Secretary

The Institution of Professional Civil

Servants,

Northumberland Street,

London $W C 2$

\section{History of "Plasmas"}

SIR,- There has been speculation as to the basis for Irving Langmuir's use of the word "plasma" to describe a particular region of an electrical discharge in a gas. I was working for Langmuir when he made this innovation about 1927, and, much later, described it in a letter to a friend at the General Electric Research and Development Center, dated April 20, 1967. The pertinent extract from this letter follows.

"Meanwhile word had come down from on high that we had better do something about mercury-arc rectifiers and converters, which were the big new things in the electrical engineering world, although at that time they were all in glass bulbs. So Langmuir began to study mercury vapor discharges. He shortly invented his probe, I did the experimental work and most of the mathematics, and we soon accumulated a lot of data about ion densities and velocity distributions in the mercury arc columns, in the positive columns of Geissler tubes, and in gasfilled thermionic tubes.

"We noticed the similarity of the discharge structures they revealed. Langmuir pointed out the importance and probable wide bearing of this fact. We struggled to find a name for it. For all members of the team realized that the credit for a discovery goes not to the man who makes it, but to the man who names it. Witness the name of our continent. We tossed around names like 'uniform discharge', 'homogeneous discharge', 'equilibrum discharge'; and for the dark or light regions surrounding electrodes, names like 'auras', 'haloes', and so forth. But one day Langmuir came in triumphantly and said he had it. $\mathrm{He}$ pointed out that the 'equilibrium' part of the discharge acted as a sort of sub-stratum carrying particles of special kinds, like high-velocity electrons from thermionic filaments, molecules and ions of gas impurities. This reminds him of of the way blood plasma carries around red and white corpuscles and germs. So he proposed to call our 'uniform discharge' a 'plasma'. Of course we all agreed.

"But then we were in for it. For a long time we were pestered by requests from medical journals for reprints of our articles. This happens to me this day. The scientific world of physics and chemistry looked askance at this uncouth word and were slow to accept it in their vocabulary. The engineering world treated it as a GE trade name. Then all of a sudden, long after I had left the laboratory, to my pleased surprise, everybody started to talk about plasmas. This happened not long before they became thermonuclear and so government subsidized. That finally put the seal of respectability on plasmas."

Yours faithfully,

HAROLD M. Mott-SMIth

6909 SW Freeway,

Texas 77036

\section{British Diary}

\section{Saturday, September 18}

Cell Proliferation and the Differential Response of Normal and Malignant Cells, Professor L. F. Lamerton, British Institute of Radiology, at Southampton. (Silvanus Thompson Memorial Lecture.)

\section{Tuesday, September 21}

Infra-red Techniques (three-day conference) Institution of Electrical Engineers; and the Institution of Electronic and Radio Engineers, at the University of Reading.

Synthesis of Sugar Phosphonates, Professor H. Paulsen, Carbohydrate Group (Chemical Society Subject Group), at Birkbeck College, University of London, Malet Street, London WC1.

\section{Wednesday, September 22}

Fibre Optics (7.30 p.m.) Dr M. Chown, Institution of Electrical Engineers, jointly with the Harlow Engineering Society, at Harlow Technical College, Harlow, Essex.

Nuclear and Particle Physics (three-day conference) Institute of Physics and the Physical Society, at the University of Oxford.

On-Line Computer Methods Relevant to Chemical Engineering (7.30 p.m. symposium) Institution of Chemical Engineers, jointly with the British Computer Society, at the University, Nottingham.

Process Pumps (three-day conference) Institution of Mechanical Engineers, at the University of Durham.

\section{Thursday, September 23}

MOS Integrated Circuits (7 p.m.) Mr R. G. Hibberd, Institution of Electrical Engineers, at the Medway College of Technology, Chatham, Kent.

Population and Pollution (two-day symposium) Eugenics Society, in the Meeting Rooms of the Zoological Society of London, Regent's Park, London NW1.
The Consumers' Association-Its Aims and Achievements (7 p.m.) Mrs Alma Williams, Oil and Colour Chemists' Association, at the Beech Tree Hotel, Maxwell Road, Beaconsfield.

\section{Friday, September 24}

Chlorinated Rubber Marine Paints (6.30 p.m.) Mr C. G. Reid, Oil and Colour Chemists' Association, Midlands Branch, at the Chamber of Commerce and Industry, 75 Harborne $\cdot$ Road, Birmingham.

Some Aspects of Metal Pretreatment and Printing (7.15 p.m.) Mr P. Gollop, Oil and Colour Chemists' Association, at the Royal Hotel, Bristol.

\section{Saturday, September 25}

Science Simulation Seminar, Institute of Mathematics and Its Applications, and Chelsea College of Science and Tech nology, at the Centre for Science Education, Bridges Place, Londo $n$ SW6. 